\title{
The Effects of Biosynthetic Insulin-Like Growth Factor-1 Supplementation on Somatic Growth, Maturation, and Erythropoiesis on the Neonatal Rat
}

\author{
ANTHONY F. PHILIPPS, BENGT PERSSON, KERSTIN HALL, MATS LAKE, ANNA SKOTTNER, \\ TRULS SANENGEN, AND VICKI R. SARA
}

\begin{abstract}
Department of Pediatrics [A.F.P.], University of Connecticut Health Center, Farmington, Connecticut 06032; Kabi Gen [M.L.] and Kabi Vitrum [A.S.], Stockholm, Sweden; Departments of Pediatrics and Pathology [T.S.], Ullevål Hospital, Oslo, Norway; and Departments of Pediatrics [B.P.], Endocrinology [K.H.], and Psychiatry
\end{abstract} [V.R.S.], Karolinska Institute, St. Goran's Hospital, Stockholm, Sweden

\begin{abstract}
Somatomedins are anabolic hormones that may stimulate growth during the perinatal period. To test this hypothesis, neonatal rats were injected with a biosynthetic somatomedin, insulin-like growth factor 1 (IGF-1) twice daily for the first 2 wk of life. Two biosynthetic IGF1 preparations of different potency were tested as well as a preparation of human growth hormone in five litters of rats. When compared to saline-injected rats, IGF-1 injected rats had increased body weight and tail length as well as specific increases in weights of liver, brain, heart, and testes. In addition, significant increases in bone marrow erythropoietic cell precursors were apparent after IGF-1 injection. IGF-1-treated neonatal rats also exhibited precocious eye opening as a sign of epithelial cell differentiation. Five additional litters of rats received similar injections but were exposed to postnatal nutritional deprivation via artificially increasing litter size. Although IGF-1 caused stimulation of bone marrow erythropoiesis and precocious eye opening, no effects of IGF-1 on somatic or organ growth could be documented. This represents the first demonstration in vivo of the anabolic effects of IGF-1 in rapidly growing neonatal rats but suggests that nutritional sufficiency may also be necessary for the full expression of somatomedin effects. (Pediatr Res 23: 298-305, 1988)
\end{abstract}

\section{Abbreviations}

CFU-E, erythroid colony-forming cell

Ep, erythropoietin

GH, growth hormone

IGF, insulin-like growth factor

HSA, human serum albumin

PCV, packed red cell volume

ANOVA, analysis of variance

Somatomedins, or IGF, comprise a family of relatively low molecular weight peptides possessing growth promoting proper-

Received June 25, 1987; accepted November 16, 1987

Correspondence and reprints Anthony F. Philipps, M.D., Department of Pediatrics, The University of Connecticut Health Center, Farmington, CT 06032.

Supported by grants from the University of Connecticut Research Foundation, the National Institutes of Health (R-01-DK26067), the Expressen Prenatal Fund, the Swedish Diabetes Association, The Bergvalis Foundation, the Norwegian Society for Fighting Cancer, and the Swedish Medical Research Council. A.F.P. was also supported by a research fellowship from the Fogarty International Center, National Institutes of Health (1 F06 TW01050). ties in a variety of mammalian cell types in vitro $(1,2)$. Although they share some structural homology with insulin $(1,2)$ and do stimulate such insulin-like effects as increased cellular glucose and amino acid uptake (3), somatomedins also possess potent mitogenic properties in cell types as diverse as fibroblasts, myocytes, chondrocytes, and erythropoietic stem cells (1-3). Of the somatomedins, IGF-1 has been studied most extensively. Its synthesis in the adult appears to be regulated by circulating $\mathrm{GH}$ concentration $(2,4)$. Somatomedins, including IGF-1, and their receptors have recently been identified in a wide variety of fetal and neonatal tissues in several species including man (5-8), raising the possibility that the rapidity of growth observed in the perinatal period may be at least partially regulated by changes in somatomedin production. However, although significant IGF-1 synthesis has been observed in the fetus and neonate (6), the mechanisms involved in regulation of IGF-1 production are unclear (9).

Unfortunately, hypotheses regarding the effects of somatomedins on growth rate or erythropoiesis have been difficult to test in other than in vitro systems because of the scarcity of purified hormone. Although somatomedins are synthesized by many cell types, no storage site has been identified and, thus, hormone purification schemes have required time-consuming concentration and separation of somatomedins from large amounts of human sera (10). Recently, genetic engineering techniques have been applied to the synthesis of somatomedins in order to provide enough purified hormone for use in in vivo animal experiments. We report the first use of two biosynthetic preparations of IGF1 in the preweanling rat in order to observe whether or not exogenous IGF-1 causes any alterations in growth or erythropoiesis during the perinatal period.

\section{MATERIALS AND METHODS}

Hormone preparation. Biosynthetic IGF-1. Two preparations of recombinant human IGF-1 were used. IGF-1 A, produced in yeast, and IGF-1 B, produced in Escherichia coli, were kindly provided by Kabi Vitrum and Kabi Gen (Stockholm, Sweden), respectively. The purity of these preparations was confirmed by amino acid composition and $\mathrm{NH}_{4}$-terminal sequence. These preparations differed in specific activity, assessed by placenta radioreceptor activity (11) as follows: IGF-1 A (5000 U/mg) and IGF-1 B (10,000 U/mg).

Biosynthetic IGF-1 was dissolved in $35 \% \mathrm{CH}_{3} \mathrm{CN}$. Aliquots were removed, placed in albumin-coated tubes, freeze dried, and before administration, dissolved in sterile saline with $0.1 \%$ HSA. 
This method gave $100 \%$ recovery of activity after syringe injection. Saline controls received identically treated aliquots of $35 \%$ $\mathrm{CH}_{3} \mathrm{CN}$, freeze dried and reconstituted in sterile saline with $0.1 \%$ HSA.

Human $G H$. Crescormon was kindly provided by Kabi Vitrum and aliquotted into 2-nmol portions.

Experimental protocol. Animals. Twelve litters of SpragueDawley rats were studied in the first 2 wk of postnatal life. Animals were supplied by a commercial breeder and birth dates were accurate to within $12 \mathrm{~h}$.

Kinetic Studies. Two litters of rats were studied on the $3 \mathrm{rd}$ or 15 th postnatal day, in order to assess the efficiency of absorption of biosynthetic IGF-1 when injected subcutaneously. In the first study, six 3-day old rats were injected subcutaneously over the lumbar spine with purified IGF-1A using plastic tuberculin syringes and 27-guage needles. Aliquots of $15 \mu \mathrm{g}$ of lyophilized hormone preparation (see below) were dissolved in delivery volumes of $50 \mu \mathrm{l}$ of normal saline immediately before injection. Blood samples were then obtained for IGF-1 assay by exsanguination via cardiac puncture under ether anesthesia. Samples were drawn at $0.25,0.5,1.0,2.0$, and $24 \mathrm{~h}$ after injection. Thus, because of the small blood volume available per animal and the limited amount of pure hormone available, each point in time was represented by blood IGF concentrations from a single animal (two animals were used to study blood levels at $24 \mathrm{~h}$ ). Two litter mates also served as noninjected controls. In addition, $10-\mu$ l blood samples were obtained by tail section before anesthesia for estimation of plasma glucose concentration. When possible, urine was obtained from the rats by gentle abdominal pressure before cardiac puncture and urine concentrations of IGF-1 were studied.

In the second study, a similar IGF-1 dose $(15 \mu \mathrm{g})$ was given to three 15-day-old rats. Because of their relatively larger blood volumes, serial blood sampling for glucose and IGF-1 concentration could both be performed by tail vein section. Thus, all three rats were studied serially at $0,0.5,1.0,5.0$, and $24 \mathrm{~h}$. Once again urine was collected when possible.

Growth Studies. Ten litters of rats were injected twice daily from day 3 through day 15 of postnatal life with biosynthetic IGF-1, GH, or saline, and the effects of hormone supplementation on growth then determined. In five of the litters, litter size was decreased from 10-13 pups per litter to eight per litter on the $3 \mathrm{rd}$ postnatal day in order to maximize pup nutrient intake during the study period ("normal litters" group). In the remaining five litters, litter size was increased from 10-13 pups per litter to 14-16 per litter using rats of identical strain, age and weight ("large litters" group). A standard technique for producing perinatal malnutrition (12), supplanted neonatal rats are usually cared for by the adoptive dam similarly to her own. Increased litter size thus causes perinatal growth retardation due to limited milk availability.

In all litters attempts were made to select, when possible, the majority of study animals (five per litter) as males. Later analysis proved, however, that no significant weight differences between males and females at 16 days were apparent in controls. An attempt was also made to match study subjects within litters for similar weight and length. Within each litter, rats were assigned to treatment groups 1 through 5 and marked using small indelible pen markings in a code on head or neck. The treatment groups were as follows: group 1, IGF-1 preparation A (Kabi-Vitrum), $15 \mu \mathrm{g}(2 \mathrm{nmol})$; group 2, IGF-1 preparation B (Kabi-Gen), $15 \mu \mathrm{g}$ (2 nmol); group 3, human GH (Kabi-Vitrum Crescormon), 42 $\mu \mathrm{g}(2 \mathrm{nmol})$; group 4, vehicle; group 5, no injection.

Injections were begun on day 3 and continued twice daily $(0900$ and $1700 \mathrm{~h})$ through postnatal day 15 . Although hormone dose remained constant throughout the study, dose per $\mathrm{g}$ body weight decreased gradually throughout the study. For IGF-1 injected rats, initial and final doses were approximately 1.8 and $0.4 \mu \mathrm{g} / \mathrm{g}$, respectively. For $\mathrm{GH}$-treated animals the initial and final doses were 5.1 and $1.2 \mu \mathrm{g} / \mathrm{g}$, respectively. Delivery volume was $50 \mu \mathrm{l}$ in rats $<20 \mathrm{~g}$ and $100 \mu \mathrm{l}$ in rats $\geq 20 \mathrm{~g}$.
Growth and Maturation Parameters. Measurements of weight, length, and tail length were obtained daily from study animals from day 3 through 16 . Length was measured as the distance between posterior occiput (a dot was placed between the ears using indelible pen ink) and anus. Tail length was measured as the distance between anus and tail tip. Estimates of maturation were performed twice daily using the following parameters. Eye Opening. Time (closest $12 \mathrm{~h}$ ) when both eyes fully open. Tooth eruption. Time (Closest $12 \mathrm{~h}$ ) when both mandibular incisors visibly erupted. Hair growth. Estimated on a scale of $0-3$ where $0=$ no visible hair, $1=$ sparse white hair on torso, $2=$ thick hair with scattered bare areas, $3=$ pelt fully covers torso.

On day 16 , approximately $16 \mathrm{~h}$ after the last injection, blood samples were obtained from each study subject via tail section for analysis of PCV, reticulocyte count, plasma glucose, and insulin concentrations. All animals were then exsanguinated via cardiac puncture while under ether anesthesia. Blood samples were allowed to clot at room temperature and the sera then stored at $-20^{\circ} \mathrm{C}$ for later analysis of rat growth hormone and IGF-1 activity.

After exsanguination, cerebrum and liver were removed from each animal, weighed, and stored for later analysis of protein and DNA content. Rat livers were removed in toto and cerebrums were removed after cleavage of the medulla at the level of the posterior occipital horns. Other organs, including heart, lungs, kidneys, spleen, testes, thymus, pituitary, and adrenals were also removed and weighed. Both femurs were removed aseptically from each animal in two of the normal sized litters and three of the large litters. The femurs were kept on $\alpha$-medium at $18^{\circ} \mathrm{C}$ until the bone marrow was expressed. The bone marrow cells were then cultured in order to determine the number of CFU-E in the respective treatment groups, and to test the in vitro sensitivity of these cells to exogenous Ep.

Analytical methods. Plasma glucose concentration was measured using the glucose oxidase technique (Beckman Instruments, Palo Alto, CA). Insulin concentration was determined using a radioimmunoassay with rat insulin standards (Novo Research Institute, Bagsvaerd, Denmark). Rat GH concentration was also measured by radioimmunoassay using rat standards. Because no cross-reactivity with human $\mathrm{GH}$ is noted in this assay, exogenous (injected) human $\mathrm{GH}$ would not be measured. IGF-1 activity was measured by two different methods: for the kinetic experiments, changes in serum somatomedin activity were performed using a radioreceptor assay (13) consisting of fetal human brain membrane, $125_{1}$-IGF- 1 and appropriate dilutions of a standard human sera. In this assay, $1 \mathrm{U}$ of somatomedin activity is arbitrarily defined as the activity present in $1 \mathrm{ml}$ of the standard serum. For the growth experiments, IGF-1 activity was measured by a specific IGF-1 radioimmunoassay (1) using chicken antihuman IGF-1 antibody and $125_{\mathrm{I}}$-IGF-1. For both assays, no attempt was made to separate binding proteins and thus results represent values in whole serum. Liver and brain tissue were treated with $5 \%$ perchloric acid according to the protocol of Sara et al. (14) for extraction of protein and DNA. Protein was measured using the method of Lowry et al. (15). DNA was measured using a modification of the Burton diphenylamine method (16). Results are expressed as mg of protein or DNA per organ. The ratio of protein content to DNA content is expressed as mg protein per mg DNA. PCV was determined by microcentrifugation. Two thousand red blood cells were counted for each reticulocyte value.

$M e t h o d$ for culturing bone marrow CFU-E. The femurs were cut at the neck before the distal end was pierced by an 18-gauge (normal litters) or 23-gauge (large litters) needle and the bone marrow flushed out with $2-3 \mathrm{ml}$ of $\alpha$-medium. Fetal calf serum (Flow Laboratories, Herts, England) was added at a concentration of $20 \%$, and a single cell suspension of both marrow plugs from each animal was obtained by gentle aspiration through a Pasteur pipette. The single cell suspensions were kept on ice and gently shaken for $4 \mathrm{~h}$. The suspensions were then filtered and centrifuged, and the cells washed and plated at a concentration 
of $5 \times 10^{4}$ nucleated cells $/ \mathrm{ml}$, as previously described for neonatal mouse liver cells $(17,18)$. Removal of cells adherent to glass was not done. A linear relationship exists between the number of erythroid colonies formed and the number of CFU-E plated; the number of colonies is also proportional to the amount of standard Ep present in the cultures in a log-dose fashion (17). In order to secure maximal stimulation, the cells from each animal studied were cultured in the absence of $\mathrm{Ep}$ as well as in the presence of four different concentrations of standard Ep (50,100, 200, $400 \mathrm{mU} / \mathrm{ml}$ ). Eight parallel wells were incubated per dose, and all animals from each litter were tested in the same experiment. The maximal response is the number of erythroid colonies formed when the cells are maximally stimulated by Ep, independent of the Ep dose at which this occurs. Thus, the maximal response reflects the number of CFU-E in the respective femoral bone marrows. Sheep plasma erythropoietin (step III, Connaught Laboratories, Ontario, Canada) served as standard Ep. The lyophilized step III preparation was dissolved in alpha-medium (Flow Laboratories) and stored at $-70^{\circ} \mathrm{C}$.

Statistical methods. To detect statistically significant differences between groups with respect to growth or biochemical parameters, grouped ANOVA and randomized block ANOVA
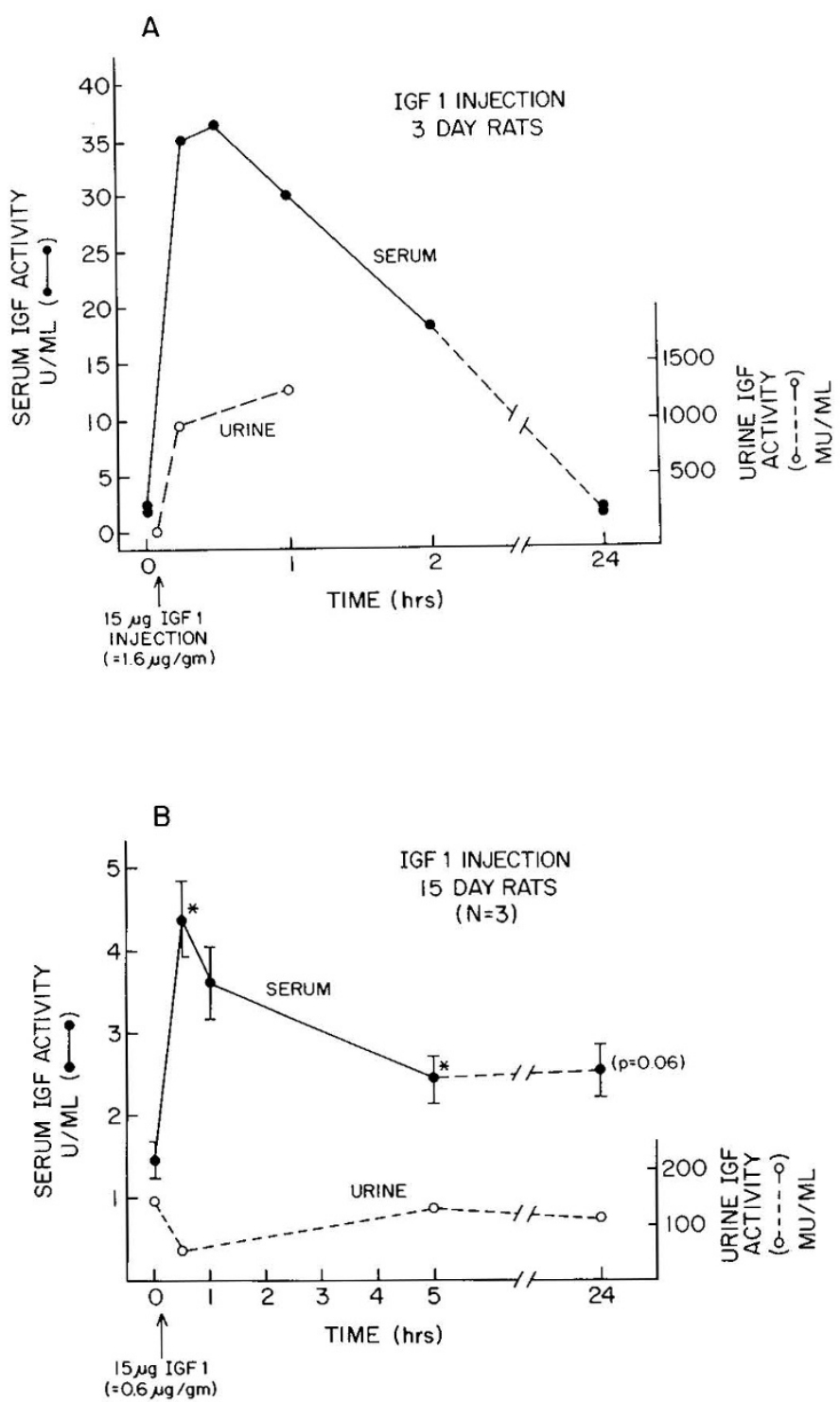

Fig. 1. $A$, serum and urine IGF-1 activity before and after subcutaneous injection of biosynthetic IGF-1 in 3 day old rats. $B$, serum and urine IGF-1 activity before and after subcutaneous injection of biosynthetic IGF-1 in 15 -day-old rats. ${ }^{*} p<0.05$. were performed. ANOVA allowed detection of differences due to "drug" (IGF-1 or GH versus control saline or no injection), litter size (normal or large), or drug-litter size interaction. If significant $(p<0.05)$ differences were obtained, individual cells were then contrasted using post hoc $t$ test comparisons. Results are expressed as mean \pm SEM unless otherwise stated.

\section{RESULTS}

Kinetic studies. No deaths were observed in any of the injected animals. Similarly, hormone injection was not accompanied by any significant detectable morbidity. Mean weight of injected 3day-old rats was $9.7 \pm 0.1 \mathrm{~g}$ and, thus, injected IGF-1 dose was approximately $1.6 \mu \mathrm{g} / \mathrm{g}$ body weight. Figure $1 \mathrm{~A}$ depicts the changes in serum somatomedin activity of the injected 3-dayold rats using the brain somatomedin receptor assay. Control somatomedin concentrations were 1.96 and $2.12 \mathrm{U} / \mathrm{ml}$ in the two controls, respectively. After injection, an increase in activity to $35-37 \mathrm{U} / \mathrm{ml}$ was observed by $15-30 \mathrm{~min}$. By $24 \mathrm{~h}$ concentrations were equal to the control value. By extrapolation from the $0.5-, 1.0-$, and $2.0-\mathrm{h}$ concentrations, control concentrations may have been reached within $4-5 \mathrm{~h}$ postinjection. Urine was available from control rats and injected rats at 0.25 and $1.0 \mathrm{~h}$. An increase in urine somatomedin concentration from 0.08 to 1.24 $\mathrm{U} / \mathrm{ml}$ was observed by $60 \mathrm{~min}$ after injection. No changes in plasma glucose concentration were noted in the injected rats.

Mean weight of 15-day-old injected rats was $25.2 \pm 0.5 \mathrm{~g}$ and thus the IGF-1 dose was approximately $0.6 \mu \mathrm{g} / \mathrm{g}$ body weight. Serum somatomedin activity (Fig. $1 B$ ) rose from $1.48 \pm 0.13$ to $4.36 \pm 0.54 \mathrm{U} / \mathrm{ml}(p<0.05)$ by $30 \mathrm{~min}$ after injection and declined thereafter. By $24 \mathrm{~h}$ postinjection, somatomedin levels were still elevated but not significantly. In contrast to 3-day-old rats, no changes in urine somatomedin concentration were observed although no urine was available at 1 or $2 \mathrm{~h}$ postinjection. No differences in plasma glucose concentration were noted in injected rats when compared to controls.

Growth of injected rats. Table 1 presents the initial (day 3) and final (day 16) weights, lengths, and tail lengths of pups from normal and large rat litters. Initial measurements were similar between all injection groups. ANOVA performed on final weight and tail length measurements of the 10 litters detected significant $(p<0.05)$ interaction between the effects of drug and litter size. A significant effect of litter size on body weight but not tail length was also observed. No statistically significant differences in crown rump lengths between treatment groups were detected by ANOVA. In the normal litters (five litters of eight pups per dam), body weights in the litter mates injected with biosynthetic IGF-1-preparation B (group 2) were significantly $(p<0.05)$ above control weight (vehicle injected group 4) by paired $t$ test analysis. In addition, tail lengths of animals in group 2 were also significantly above those of the control group $(p<0.05)$. Although mean crown rump length in group 2 was also increased $(7.0 \pm 0.3$ versus $6.8 \pm 0.2 \mathrm{~cm})$, the difference was not statistically significant. As shown in Figure 2, increases in body growth of IGF-1-B (group 2) rats versus controls were present by the 11 th postnatal day for body weight and by the 13th postnatal day for tail length.

Injections of the less potent IGF-1 preparation (preparation A) or of human growth hormone were not associated with observed changes in growth in any of the five normal litters studied. Noninjected litter mates (group 5) had growth parameters similar to those of the vehicle-injected control animals, confirming the safety of the method used in reconstitution of the hormones.

In the five large litters receiving relatively poor nutrition, control animals in group 4 had body weights that were significantly below those of their normally nourished counterparts [ 28.6 \pm 2.1 versus $35.0 \pm 1.7 \mathrm{~g}$, respectively $(p<0.05$ by unpaired $t$ test)]. Neither tail nor crown-rump lengths were statistically 
different between normally nourished and malnourished rat pups, however. Unlike the pups in normal litters, IGF-1 injection in rat pups of large litters was not associated with any increase in growth parameters when compared to control rats.

Maturation of injected rats. Analysis of variance detected a significant effect of drug $(p<0.05)$ but not nutrition $(p<0.10)$ upon time of eye opening in the rat litters. By paired $t$ test analysis, time of eye opening (Table 2) was significantly accelerated by injection of IGF-1 B in large litters and in pooled data from all 10 litters. Because of the small sample size, time of eye opening between groups given IGF-1 B versus saline in normal litters only approached statistical significance $(p<0.07)$. In contrast, neither IGF-1 nor growth hormone accelerated time of tooth eruption or hair production.

Blood studies (Table 3). Significant effects of drug on both glucose concentration and insulin/glucose ratios were detected by ANOVA among the 10 litters. By $t$ test analysis, however, the differences were due to mild hypoglycemia and an increased insulin/glucose ratio among growth hormone injected rats of normal litters when compared to saline-injected litter mates. Plasma glucose and insulin concentrations in the IGF-1 injected rats were similar to control values. No significant effects of litter size or drug-litter size interaction were detected for the parameters of glucose, insulin, or insulin/glucose ratio between treatment groups. Similarly, no differences in rat growth hormone were noted between groups. A significant effect of litter size on whole blood radioimmunoassay-IGF-1 concentration was detected by ANOVA. No effect of drug or drug-litter size interaction were noted. Overall, pups from large litters had blood radioimmunoassay IGF-1 concentrations $70.2 \pm 4.0 \%$ of those of normal litters $(p<0.05)$.

Erythropoietic studies (Table 4). There were no significant differences in reticulocyte counts between the five treatment groups within each litter size and there were no differences between the respective treatment groups within normal or large litters, respectively. No differences were found in PCV between the five treatment groups within each litter size. However, rat pups in the five treated groups of large litters had increased PCV when compared with corresponding animals of treated groups within the normal litters $(p<0.001)$.

In the rat pups from the two normal sized litters studied, group 2 animals showed a significantly higher maximal response with respect to numbers of bone marrow CFU-E than all other treatment groups $(p<0.05)$. Neither groups 1 (IGF-1A) nor 3 (GH) CFU-E were significantly different from control (group 4)

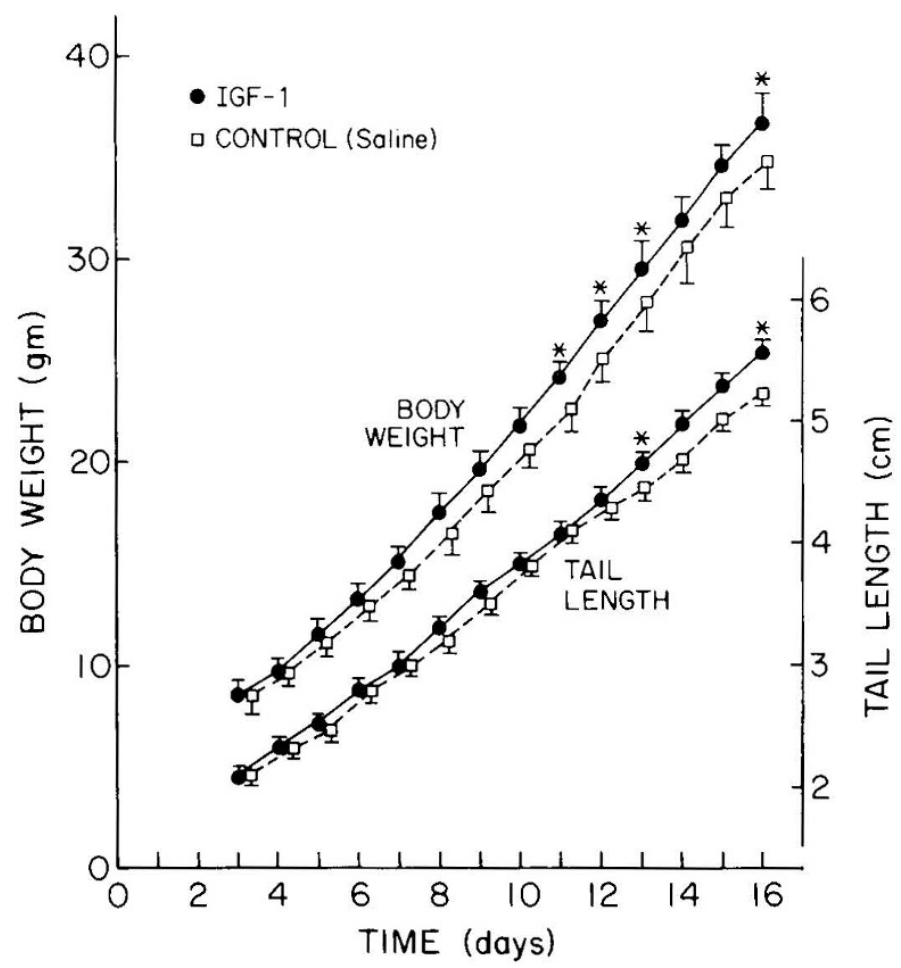

Fig. 2. Changes in body weight and tail length of control (saline injected) rats and IGF-1 (preparation B) injected rats in normal litters over the 2-wk experimental period.

Table 2. Comparison of time of eye opening between IGF-1 injected and control rats

\begin{tabular}{lcc}
\hline & $\begin{array}{c}\text { IGF-1B } \\
(n=5)\end{array}$ & $\begin{array}{c}\text { Control } \\
(n=5)\end{array}$ \\
\hline Normal litters & $15.4 \pm 0.2$ & $16.0 \pm 0$ \\
& $(p<0.07)$ & \\
Large litters & $14.5 \pm 0.2$ & $15.7 \pm 0.4$ \\
& $(p<0.001)$ & \\
All litters & $15.0 \pm 0.3$ & $15.9 \pm 0.3$ \\
& $(p<0.001)$ & \\
\hline
\end{tabular}

Table 1. Initial and final growth parameters of injected versus control rat pups in normal and large litters

\begin{tabular}{|c|c|c|c|c|c|c|}
\hline & Day & $\begin{array}{c}\text { IGF-1A } \\
1 \\
\end{array}$ & $\begin{array}{c}\text { IGF-1B } \\
2 \\
\end{array}$ & $\begin{array}{c}\mathrm{GH} \\
3 \\
\end{array}$ & $\begin{array}{c}\text { Vehicle } \\
4\end{array}$ & $\begin{array}{c}\text { No } \\
\text { injection } \\
5 \\
\end{array}$ \\
\hline \multicolumn{7}{|l|}{ Normal litters } \\
\hline \multirow[t]{2}{*}{ Wt (g) } & 3 & $8.2 \pm 0.4$ & $8.5 \pm 0.4$ & $8.2 \pm 0.4$ & $8.3 \pm 0.4$ & $8.6 \pm 0.4$ \\
\hline & 16 & $33.9 \pm 1.0$ & $36.7 \pm 1.3^{*}$ & $35.9 \pm 1.5$ & $35.0 \pm 1.7$ & $34.4 \pm 1.3$ \\
\hline \multirow{2}{*}{ Length $(\mathrm{cm})$} & 3 & $4.5 \pm 0.2$ & $4.6 \pm 0.4$ & $4.4 \pm 0.2$ & $4.4 \pm 0.1$ & $4.5 \pm 0.1$ \\
\hline & 16 & $6.8 \pm 0.1$ & $7.0 \pm 0.3$ & $6.7 \pm 0.1$ & $6.8 \pm 0.2$ & $6.6 \pm 0.1$ \\
\hline \multirow{2}{*}{ Tail length $(\mathrm{cm})$} & 3 & $2.0 \pm 0.1$ & $2.1 \pm 0.1$ & $2.1 \pm 0.1$ & $2.1 \pm 0.1$ & $2.1 \pm 0.1$ \\
\hline & 16 & $5.2 \pm 0.1$ & $5.5 \pm 0.1^{*}$ & $5.3 \pm 0.1$ & $5.3 \pm 0.1$ & $5.3 \pm 0.1$ \\
\hline \multicolumn{7}{|l|}{ Large litters } \\
\hline \multirow[t]{2}{*}{ Wt (g) } & 3 & $9.1 \pm 1.3$ & $9.4 \pm 0.8$ & $9.1 \pm 0.8$ & $9.3 \pm 0.8$ & $9.1 \pm 0.7$ \\
\hline & $16 \dagger$ & $27.9 \pm 1.9$ & $27.0 \pm 1.6$ & $30.6 \pm 2.3$ & $28.6 \pm 2.1$ & $27.9 \pm 2.0$ \\
\hline \multirow[t]{2}{*}{ Length (cm) } & 3 & $4.4 \pm 0.2$ & $4.5 \pm 0.1$ & $4.3 \pm 0.1$ & $4.5 \pm 0.1$ & $4.4 \pm 0.1$ \\
\hline & 16 & $6.2 \pm 0.2$ & $6.2 \pm 0.2$ & $6.4 \pm 0.2$ & $6.2 \pm 0.2$ & $6.2 \pm 0.3$ \\
\hline \multirow[t]{2}{*}{ Tail length $(\mathrm{cm})$} & 3 & $2.3 \pm 0.1$ & $2.3 \pm 0.1$ & $2.4 \pm 0.1$ & $2.3 \pm 0.1$ & $2.4 \pm 0.1$ \\
\hline & 16 & $5.2 \pm 0.3$ & $5.3 \pm 0.1$ & $5.3 \pm 0.2$ & $5.2 \pm 0.2$ & $5.2 \pm 0.3$ \\
\hline
\end{tabular}

$* p<0.05$ compared to group 4 or 5 .

$\dagger p<0.05$ between normal and large litters, all groups. 
Table 3. Blood concentrations of glucose, insulin, GH, and IGF-1 in rats from normal and large litters on day 16 (mean $\pm S E M)$

\begin{tabular}{|c|c|c|c|c|c|}
\hline & $\begin{array}{c}\text { IGF-1(A) } \\
1\end{array}$ & $\begin{array}{c}\text { IGF-1(B) } \\
2\end{array}$ & $\begin{array}{c}\text { GH } \\
3\end{array}$ & $\begin{array}{c}\text { Vehicle } \\
4\end{array}$ & $\begin{array}{c}\text { No } \\
\text { injection } \\
5\end{array}$ \\
\hline \multicolumn{6}{|l|}{ Normal litters } \\
\hline Plasma glucose (mg/dl) & $128 \pm 1$ & $136 \pm 2$ & $122 \pm 3^{*}$ & $138 \pm 3$ & $127 \pm 3$ \\
\hline Plasma insulin $(\mathrm{ng} / \mathrm{ml})$ & $1.10 \pm 0.17$ & $1.10 \pm 0.11$ & $1.33 \pm 0.22$ & $0.85 \pm 0.25$ & $0.93 \pm 0.11$ \\
\hline Insulin/glucose $\left(\mathrm{ng} / \mathrm{mg} \times 10^{-1}\right)$ & $8.47 \pm 1.27$ & $8.10 \pm 0.74$ & $10.91 \pm 1.87^{*}$ & $6.29 \pm 1.88$ & $7.29 \pm 0.73$ \\
\hline Rat GH (ng/ml) & $3.0 \pm 0.4$ & $4.0 \pm 0.6$ & $5.2 \pm 0.8$ & $3.3 \pm 0.2$ & $6.5 \pm 2.5$ \\
\hline Radioimmunoassay-IGF-1 activity & $272 \pm 27$ & $298 \pm 45$ & $352 \pm 38$ & $436 \pm 107$ & $306 \pm 53$ \\
\hline \multicolumn{6}{|l|}{ Large litters } \\
\hline Plasma glucose $(\mathrm{mg} / \mathrm{dl})$ & $128 \pm 2$ & $128 \pm 3$ & $129 \pm 3$ & $129 \pm 3$ & $134 \pm 6$ \\
\hline Plasma insulin $(\mathrm{ng} / \mathrm{ml})$ & $0.75 \pm 0.34$ & $0.98 \pm 0.18$ & $0.98 \pm 0.22$ & $0.91 \pm 0.13$ & $1.11 \pm 0.16$ \\
\hline Insulin/glucose $\left(\mathrm{ng} / \mathrm{mg} \times 10^{-1}\right)$ & $5.71 \pm 2.48$ & $7.51 \pm 1.42$ & $7.59 \pm 1.91$ & $7.04 \pm 1.10$ & $8.33 \pm 1.30$ \\
\hline Rat $\mathrm{GH}(\mathrm{ng} / \mathrm{ml})$ & $3.6 \pm 0.2$ & $3.4 \pm 0.2$ & $3.8 \pm 0.3$ & $3.2 \pm 0.3$ & $5.6 \pm 1.7$ \\
\hline RIA-IGF-1 activity $\dagger$ & $227 \pm 6$ & $212 \pm 9$ & $242 \pm 13$ & $238 \pm 12$ & $222 \pm 21$ \\
\hline
\end{tabular}

$* p<0.05$ compared to groups 4 or 5 .

$\dagger p<0.05$ between normal and large litters, all groups.

Table 4. Erythropoietic parameters measured in injected and control rat pups in normal and large litters

\begin{tabular}{|c|c|c|c|c|c|}
\hline & $\begin{array}{c}\text { IGF-(A) } \\
1\end{array}$ & $\begin{array}{c}\text { IGF-(B) } \\
2 \\
\end{array}$ & $\begin{array}{c}\mathrm{GH} \\
3 \\
\end{array}$ & $\begin{array}{c}\text { Vehicle } \\
4\end{array}$ & $\begin{array}{c}\text { No } \\
\text { injection } \\
5 \\
\end{array}$ \\
\hline \multicolumn{6}{|l|}{ Normal litters } \\
\hline $\begin{array}{l}\text { Maximal response (colonies } / 5 \cdot 10^{4} \text { cells) } \\
\quad(n=16)\end{array}$ & $301 \pm 15^{*}$ & $346 \pm 12 \dagger$ & $286 \pm 12$ & $303 \pm 11^{*}$ & $249 \pm 19$ \\
\hline Reticulocyte count $(\%)(n=5)$ & $9.7 \pm 2.5$ & $12.7 \pm 3.0$ & $9.8 \pm 1.2$ & $9.8 \pm 0.7$ & $7.3 \pm 1.2$ \\
\hline $\operatorname{PCV}(\%)(n=5)$ & $32.0 \pm 1.6$ & $30.6 \pm 1.6$ & $29.8 \pm 1.3$ & $31.2 \pm 1.0$ & $32.4 \pm 1.1$ \\
\hline \multicolumn{6}{|l|}{ Large litters } \\
\hline $\begin{array}{l}\text { Maximal response (colonies } / 5 \cdot 10^{4} \text { cells) } \\
(n=16-24)\end{array}$ & $329 \pm 20 \ddagger$ & $298 \pm 23 \ddagger$ & $367 \pm 24 \ddagger \S \|$ & $222 \pm 13 \|$ & $206 \pm 27$ \\
\hline Reticulocyte count $(\%)(n=3-5)$ & $5.9 \pm 1.6$ & $8.6 \pm 1.4$ & $7.1 \pm 1.2$ & $7.5 \pm 2.1$ & $5.5 \pm 1.2$ \\
\hline PCV $(\%)(n=5)$ & $36.7 \pm 1.6$ & $37.2 \pm 1.6$ & $33.0 \pm 1.5$ & $34.4 \pm 1.3$ & $34.8 \pm 1.7$ \\
\hline
\end{tabular}

$* p<0.05$ compared to group 5 .

$\dagger p<0.05$ compared to all other groups.

$\ddagger p<0.05$ compared to groups 4 or 5 .

$\S p<0.05$ compared to group 2 .

$\| p<0.05$ between normal and large litters, corresponding groups.

I $p<0.05$ between normal and large litters, all groups.

values. In animals from large litters, groups 1, 2, and 3 all showed higher maximal responses regarding numbers of CFU-E than control animals $(p<0.02)$. Interestingly, CFU-E in group 3 $(\mathrm{GH})$ animals exceeded $(p<0.05)$ those of group 2.

The bone marrow cells from all litters showed very similar responses to stimulation by exogenous Ep within the range of doses tested. At an Ep concentration of $50 \mathrm{mU} / \mathrm{ml}$ all but one group (group 5, large litters) showed from 75 to $91 \%$ of the respective maximal responses. When $100 \mathrm{mU} / \mathrm{ml}$ of Ep were added, all groups showed between 85 and $100 \%$ of maximal response. Thus no differences in in vitro sensitivity to Ep between the various CFU-E populations could be demonstrated.

Organ growth in injected rats. ANOVA performed on organ weights of the 10 litters of rats detected significant effects of druglitter size interaction on the wet weights of liver, brain, heart, and testes suggesting a drug effect only in normal litters. Figure 3 depicts selected mean organ weights of rat pups in the five normally nourished litters. Injection of IGF-1 preparation A was not associated with any increased growth when compared to controls. Increases in growth of liver, brain, heart, and testes were noted in rat pups injected with IGF-1 preparation B when compared to vehicle injected litter mates, but the weights of spleen, kidneys, adrenals, lungs, thymus, or pituitary were similar to controls. The increased organ weights observed were commensurate with body growth and thus organ weight to body weight ratios were similar between IGF-1B injected (group 2) and vehicle-injected (group 4) rats. GH injection was associated with an approximately $15 \%$ increase in lung growth and a marked increase in lung weight to body weight ratio in comparison to the vehicle-injected controls $(p<0.05)$. In contrast, adrenal weight in $\mathrm{GH}$ injected rats was $35 \%$ below control $(p<$ 0.05 ).

In the five large litters, control weights of liver, heart, and spleen, but not brain, were significantly below those of the controls in the well nourished litters although a greater degree of interlitter variation was present. In contrast to the well nourished litters, neither IGF-1 nor growth hormone injections were associated with any significant changes in organ growth.

In most organs studied, organ weight per body weight ratios were similar between normally nourished and malnourished litters. In contrast, control rat pups of malnourished litters had increased brain weight to body weight ratios when compared to normally nourished litters $(3.4 \pm 0.3$ versus $2.7 \pm 0.1 \%$, respectively, $p<0.001$ ). IGF-1 injections were not associated with significant changes in these ratios in either of the two nutrition groups.

Protein and DNA contents were measured in livers and brains of rat pups from all 10 litters and are presented in Table 5. By ANOVA and subsequent $t$ test analysis, increased litter size was associated with a decrease in both total protein and DNA content 
in livers but not brains of rats in all treatment groups when compared to similarly treated rat pups of normal litters. No statistically significant differences in protein/DNA ratios related to litter size were noted. Drug-litter size interaction was apparent only in analysis of total liver protein and was due to a significant

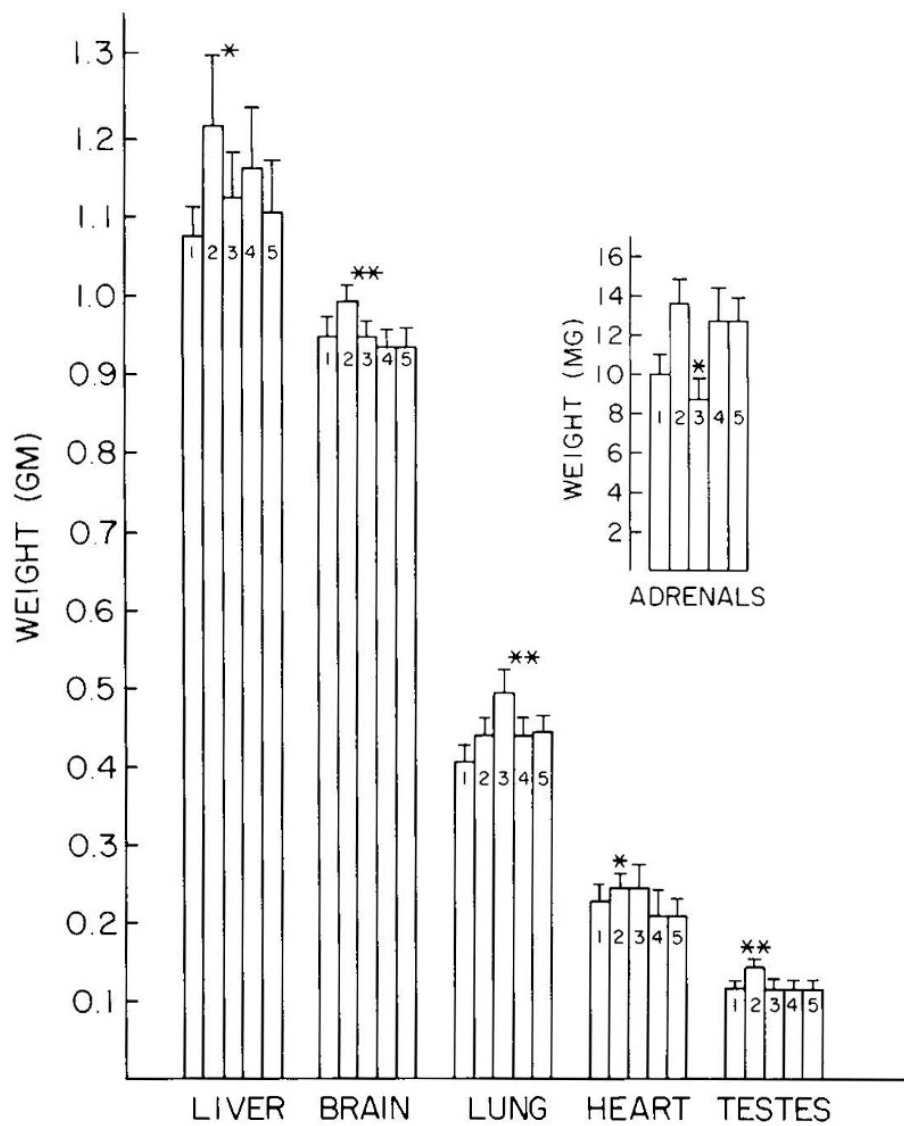

Fig. 3. Selected organ weights of study animals in normal litters. Numbers in bars refer to treatment groups as in "Materials and methods." ${ }^{*} p<0.05,{ }^{* *} p<0.01$ when compared to controls (groups 4 or 5 ). increase in liver protein of IGF-1B injected rats when compared to noninjected controls in normal litters. In normal litters brain protein content was slightly elevated above control $(67.0 \pm 2.3$ versus $64.0 \pm 2.1 \mathrm{mg}$, respectively), but the difference was not statistically significant. IGF-1 injections had no effect on brain DNA or liver DNA content in normal litters. IGF-1 injections caused no discernible changes in protein or DNA content of livers and brains in growth-retarded rat pups from large litters, although there was a trend $(p<0.1)$ toward decreased brain protein content in pups from large litters given either IGF-1A or B.

\section{DISCUSSION}

Somatomedins are thought to play a role in the regulation of mammalian cellular growth $(1,2)$. IGF-1 has been most extensively studied in this respect and has been shown to stimulate cell replication and DNA synthesis in a variety of cell types including fibroblasts (19), myoblasts (19), chondrocytes (20), oligodendrocytes $(21)$, and erythroid progenitor cells $(2,22)$. In addition, IGF-1 stimulates insulin-like metabolic effects of increasing glucose and amino acid entry into muscle and adipose tissue (2). IGF-1 synthesis in the adult is regulated in large part by secretion of growth hormone $(1,2,4)$. Recent in vivo studies using both impure and purified IGF-1 preparations have demonstrated significant growth promoting properties of IGF-1 when injected into postweanling normal rats (23), adult hypophysectomized rats $(24,25)$, or congenitally hypopituitary (Snell dwarf) mice (26). In the latter, growth in IGF-1 injected animals was equivalent to that of growth hormone supplemented animals and far exceeded that of controls.

In fetal and early neonatal life, the synthesis of somatomedins appears not to be under control of growth hormone secretion (9). Both human anencephalic fetuses (27) and fetal sheep exposed to pituitary ablation (28) have relatively normal somatic growth. In the latter case, as well as in normal human fetuses (13), normal levels of circulating somatomedins are present. In the rat, growth also appears to be independent of $\mathrm{GH}$ secretion until approximately 20 days after birth (29). Little is known about regulation of somatomedin synthesis in the perinatal period but nutrition may play a role. In accordance with the above information in the rat, significant development changes

Table 5. Comparison of protein and DNA contents in livers and brains of rats from normal and large litters (mean \pm SEM)

\begin{tabular}{|c|c|c|c|c|c|}
\hline & $\begin{array}{c}\text { IGF-1A } \\
1 \\
\end{array}$ & $\begin{array}{c}\text { IGF-1B } \\
2 \\
\end{array}$ & $\begin{array}{c}\mathrm{GH} \\
3 \\
\end{array}$ & $\begin{array}{c}\text { Vehicle } \\
4 \\
\end{array}$ & $\begin{array}{c}\text { No injection } \\
5 \\
\end{array}$ \\
\hline \multicolumn{6}{|l|}{ Liver } \\
\hline \multicolumn{6}{|l|}{ Total protein $(\mathrm{mg})$} \\
\hline Normal litters & $149.0 \pm 16.4$ & $187.1 \pm 19.8^{*}$ & $144.6 \pm 18.9$ & $167.9 \pm 24.1$ & $160.4 \pm 25.2$ \\
\hline Large litters & $87.6 \pm 2.4$ & $107.6 \pm 6.4$ & $103.9 \pm 8.6$ & $110.7 \pm 10.7$ & $113.2 \pm 12.4$ \\
\hline \multicolumn{6}{|l|}{ Total DNA (mg) } \\
\hline Normal litters & $4.53 \pm 0.06$ & $4.83 \pm 0.14$ & $4.71 \pm 0.13$ & $4.82 \pm 0.17$ & $4.48 \pm 0.14$ \\
\hline Large litters $\dagger$ & $3.56 \pm 0.23$ & $3.53 \pm 0.34$ & $4.00 \pm 0.32$ & $4.05 \pm 0.33$ & $3.68 \pm 0.22$ \\
\hline \multicolumn{6}{|l|}{ Protein/DNA } \\
\hline Normal litters & $32.9 \pm 3.6$ & $37.5 \pm 4.2$ & $30.5 \pm 3.5$ & $34.6 \pm 4.4$ & $35.0 \pm 5.0$ \\
\hline Large litters & $25.0 \pm 1.1$ & $28.2 \pm 1.2$ & $26.0 \pm 1.7$ & $27.6 \pm 1.7$ & $30.5 \pm 2.4$ \\
\hline \multicolumn{6}{|l|}{ Brain } \\
\hline \multicolumn{6}{|l|}{ Total protein $(\mathrm{mg})$} \\
\hline Normal litters & $67.0 \pm 2.9$ & $67.0 \pm 2.3$ & $65.4 \pm 2.7$ & $64.0 \pm 2.1$ & $64.7 \pm 1.8$ \\
\hline Large litters & $59.9 \pm 0.2$ & $60.0 \pm 2.0$ & $64.1 \pm 3.5$ & $67.1 \pm 2.9$ & $65.2 \pm 1.0$ \\
\hline \multicolumn{6}{|l|}{ Total DNA (mg) } \\
\hline Normal litters & $1.11 \pm 00.5$ & $1.07 \pm 0.02$ & $1.05 \pm 0.02$ & $1.05 \pm 0.03$ & $1.03 \pm 0.03$ \\
\hline Large litters & $1.14 \pm 0.02$ & $1.09 \pm 0.06$ & $1.11 \pm 0.05$ & $1.14 \pm 0.03$ & $1.07 \pm 0.01$ \\
\hline \multicolumn{6}{|l|}{ Protein/DNA } \\
\hline Normal litters & $61.0 \pm 4.7$ & $63.0 \pm 2.7$ & $62.4 \pm 2.9$ & $61.9 \pm 2.7$ & $63.0 \pm 2.0$ \\
\hline Large litters & $52.5 \pm 0.8$ & $55.6 \pm 2.6$ & $57.9 \pm 3.3$ & $58.9 \pm 1.8$ & $61.2 \pm 0.7$ \\
\hline
\end{tabular}

$* p<0.05$ compared to group 4 or 5 .

$\dagger p<0.05$ between normal and large litters, all groups. 
occur in somatomedin synthesis during the perinatal period $(9$, 30). Rat IGF-2 [multiplication stimulating activity (30)], a close homologue of human IGF-2, is the predominant circulating somatomedin in the fetal rat. Rat IGF-1 levels (similar to human IGF-1) rise in serum after the 2 nd to $3 \mathrm{rd} \mathrm{wk}$ of postnatal life, concurrent with increases in $\mathrm{GH}$ and $\mathrm{GH}$ receptor concentrations. Although D'Ercole et al. $(6,7,31)$ have shown that multiple fetal tissues have the capacity for somatomedin synthesis, no direct evidence for somatomedin regulation of growth in the perinatal period has previously been demonstrated.

The access to potent and highly purified preparations of IGF1 using recombinant gene technology have allowed for the initial assessment of in vivo growth promoting properties of somatomedins in the growing neonatal rat. In contrast to previous studies in hypopituitary adult animals, the present studies document that IGF-1, but not GH supplementation, caused increased growth in otherwise rapidly growing neonatal rats. The accelerated growth noted in these studies was comprised of increased somatic and skeletal growth as well as specific increases in the gross weights of brain, liver, heart, and testes. The increases in all of the above organs were proportional to the increases in overall growth observed.

Subcutaneous injections of reconstituted IGF-1 caused elevated somatomedin blood levels within $15 \mathrm{~min}$ of injection. Although the methodology and small sample size precluded measurement of serum half-life of injected IGF-1, the data would suggest that serum concentrations of IGF-1 after a single injection were elevated above control for no more than $4 \mathrm{~h}$ in 3-day-old rats, with considerably lower levels achieved using the same dose in 15-day-old rats. Because little is known of the in vivo dose response, kinetics of decay, or volume of distribution of exogenously administered somatomedins, dose and timing of injection in the current study was a matter of trial and error. However, in adult Snell dwarf mice injected 3 times per day for 4 wk with approximately twice the amount of IGF-1 per g body weight as used in our study, a weight increase of $25 \%$ was noted (26). Using continuous subcutaneous infusions of IGF-1 in adult hypopituitary rats over a 6 day period, Froesch et al. (2) and Schoenle et al. (24) noted a 5-7\% weight increase as well as an overall increase in serum IGF-1 concentration. The highest dose per g body weight per day given was approximately $30 \%$ of that used in our series of experiments on day 3 of life but was similar to the weight-adjusted dose given on day 15 of life. In both studies $(2,24)$ a clear relationship between dose and growth response was observed. The demonstration in the current series of experiments that a second less biologically active IGF-1 preparation (IGF-1A) caused no changes in growth suggests that a dose-related phenomenon may be operative for stimulating growth in neonatal rats as well. In this respect, a significant fraction of injected somatomedin herein may have been lost via urinary excretion, particularly in the first several days of the study. Although circulating somatomedins are almost exclusively found attached to several serum binding proteins $(7,30)$, it is likely that IGF-1 injection in the neonates caused large elevations in free IGF-1 concentration in blood which, similar to insulin (32), might be cleared in neonatal urine to a greater extent than in the adult.

IGF-1 injections in well-nourished neonatal rats caused significant increases in the weights of several organs, specifically brain, liver, heart, and testes, as well as increasing overall body weight and tail length. In contrast, adult Snell dwarf mice (26) injected with IGF-1 showed increases in carcass and skeletal growth but no changes in weight of individual internal organs. Because these organs in the neonatal rat are undergoing a rapid growth spurt during the first 2 wk of postnatal life $(33,34)$, the above data suggest that IGF-1 may stimulate excessive organ growth during this period, but not in adulthood. Because of the relatively small sample size and modest changes observed, it is not clear as to whether excessive growth of the livers and brains of IGF-1 injected rats was due primarily to increases in cell number
(DNA), cell size (protein), or lipid content although clear increases in liver protein content were observed.

The number of bone marrow CFU-E increased in IGF-1B treated, normally nourished rats. Little is known about the effect of IGF-1 on EP production and sensitivity of the erythroid progenitor cells to Ep in vivo. Unfortunately there was not enough remaining blood for serum Ep determination. However, no alteration in CFU-E responsivity to Ep in vitro was detected in these series of experiments. Erythroid progenitor cells less differentiated than CFU-E are relatively insensitive to Ep. These findings may be interpreted to suggest an effect of IGF-1 bone marrow erythropoiesis independent of Ep. No effects of IGF-1 on PCV or reticulocyte counts were observed and thus the relationship between IGF-1-induced increases in CFU-E in bone marrow and peripheral blood parameters is unclear.

$\mathrm{GH}$, as expected, caused no increases in somatic or skeletal growth in neonatal rats, and there were no increases in blood somatomedin concentration after chronic GH injection. However, significant effect of $\mathrm{GH}$ on overall lung growth was observed. Whether or not this growth stimulation is mediated by somatomedins or other growth factors (35) is not known.

To test the hypothesis that somatomedins were necessary but not sufficient for growth in the neonatal period, malnutrition was introduced as a second variable. Malnutrition was induced by increasing litter size and produced an overall reduction in body weight in rats from large litters of $20-25 \%$ when compared to normally nourished controls. IGF-1 injections caused no changes in somatic or organ growth in malnourished animals, thus suggesting that caloric insufficiency blocks the growthpromoting properties of somatomedin injection. IGF-1A- and Btreated rat pups in the large litters, however, had increased numbers of CFU-E, suggesting that IGF-1 may exert a direct effect on bone marrow erythropoiesis independent of growth per se. Although $\mathrm{GH}$ is known to stimulate erythropoiesis in adult rodents (36), it is unclear why $\mathrm{GH}$ herein only caused increases in bone marrow CFU-E in treated animals of large litter size. In this regard, other factors probably exist in determining the rate of erythropoiesis in the neonate. Although starvation depresses erythropoiesis in adult rats (37), the opposite effect has been observed in neonatal rats (38), suggesting a possible mechanism for the observed increase in PCV of rats from large litters, irrespective of treatment group.

Although IGF-1 did not alter the normal timing of tooth eruption or hair development in newborn rats, eye opening was accelerated significantly. This effect, unlike the stimulation of somatic and skeletal growth, occurred in well-nourished and malnourished litters. As a marker of epithelial cell differentiation (39), time of eye opening has been used to test the effects of other potential growth factors on differentiation. Of interest is the finding that epidermal growth factor, a peptide hormone structurally unrelated to somatomedins (40), has a similar effect on stimulation of eye opening. The significance of these findings is unclear at present.

Thus, in summary, a pure and potent biosynthetic preparation of IGF-1 when injected twice daily into rats for the first $2 \mathrm{wk}$ of postnatal life, causes significant increases in body weight, skeletal growth, and specific organ growth, as well as accelerating eye opening, a crude estimate of epithelial cell differentiation. IGF1 also caused a significant increase in the number of bone marrow CFU-E. The present data suggest that this represents a direct erythropoietic stimulatory effect of IGF-1 in vivo, independent of increases in other growth parameters. Growth stimulation due to IGF-1 injection did not occur in malnourished rat pups, however, suggesting that IGF-1 stimulated growth in the neonate is the result of a complex interaction between nutritional intake and somatomedin synthesis.

Acknowledgments. The authors acknowledge the expert technical assistance of Inger Bursell, Lollo Gustavsson, Barbro Sjö- 
gren, and Kirsten Ostbye and the secretarial assistance of Mary Ann Peifer.

\section{REFERENCES}

1. Hall K, Sara VR 1983 Growth and somatomedins. Vitam Horm 40:175-233

2. Froesch ER, Schmid C, Schwander J, Zapf J 1985 Actions of insulin-like growth factors. Ann Rev Physiol 47:443-467

3. O'Keefe EJ, Pledger WJ 1983 A model of cell cycle control: sequential events regulated by growth factors. Mol Cell Endocrinol 31:167-186

4. Hall K, Brandt J, Engberg G, Fryklund L 1979 Immunoreactive somatomedin $\mathrm{A}$ in human serum. J Clin Endocrinol Metab 48:271-278

5. Rechler MM, Nissley SP 1985 The nature and regulation of the receptors for insulin-like growth factors. Ann Rev Physiol 27:425-442

6. D'Ercole AJ, Applewhite GT, Underwood LE 1980 Evidence that somatomedin is synthesized by multiple tissues in the fetus. Dev Biol 75:315-328

7. D'Ercole AJ, Underwood LE 1980 Ontogeny of somatomedin during development in the mouse. Dev Biol 79:33-45

8. Sara VR, Hall K, Mizaki M, Fryklund L, Christensen N, Wetterberg L 1983 The ontogenesis of somatomedin and insulin receptors on the human fetus. $\mathrm{J}$ Clin Invest 71:1084-1094

9. Adams SO, Nissley SP, Handwerger S, Rechler MM 1983 Developmental patterns of insulin-like growth factor-I and -II synthesis and regulation in rat fibroblasts. Nature 302:150-153

10. Engberg G, Carlquist M, Jörnvall H, Hall K 1984 The characterization of somatomedin $\mathrm{A}$, isolated by microcomputer-controlled chromatography, reveals an apparent identity to insulin-like growth factor 1. Eur J Biochem 143:117-124

11. Marshall RN, Underwood LE, Viona SJ, Foushee DB, Van Wyk JJ 1974 Characterization of the insulin and somatomedin-C receptors in human placental cell membranes. J Clin Endocrinol Metab 39:283-292

12. Griffin WST, Woodward DJ, Chanda R 1977 Malnutrition and brain development: cerebellar weight, DNA, RNA, protein and histological correlations. J Neurochem 28:1269-1279

13. Sara VR, Hail K, Rodeck CH, Wetterberg L 1981 Human embryonic somatomedin. Proc Natl Acad Sci USA 78:3175-3179

14. Sara VR, Lazarus L, Stuart MC, King T 1974 Fetal brain growth; selective action by growth hormone. Science 186:446-447

15. Lowry OH, Rosebrough NJ, Farr HL, Randall RJ 1959 Protein measurement with the Folin phenol reagent. J Biol Chem 193:265-275

16. Giles KW, Myers A 1965 An improved diphenylanine method for the estimation of deoxyribonucleic acid. Nature 206:93

17. Hågå $\mathrm{P}$, Falkanger $\mathrm{B} 1979$ In vitro assay for erythropoietin: erythroid colony formation in methyl cellulose used for the measurement of erythropoietin in plasma. Blood 53:1172-1181

18. Wider $\phi$ e T-E, Sanengen T, Halvorsen S 1983 Erythropoietin and uremic toxicity during continuous ambulatory peritoneal dialysis. Kidney Intern 24(suppl 16):S208-S217

19. Hill DJ, Crace CJ, Strain AJ, Milner RDG 1986 Regulation of amino acid uptake and deoxyribo nucleic acid synthesis in isolated human fetal fibroblasts and myoblasts: effect of human placental lactogen, somatomedin-C, multiplication-stimulating activity, and insulin. J Clin Endocrinol Metab 62:753-760

20. Watanabe N, Rosenfeld RG, Hintz RL, Dollar LA, Siwth RL 1985 Character- ization of a specific insulin-like growth factor-I/somatomedin-C receptor on high density, primary monolayer cultures of bovine articular chondrocytes: regulation of receptor concentration by somatomedin, insulin and growth hormone. J Endocrinol 107:275-283

21. McMorris FA, Smith TM, DeSalvo S, Furlanetto RW 1987 Insulin-like growth factor I/somatomedin C: a potent inducer of oligodendrocyte development. Proc Natl Acad Sci USA 83:822-826

22. Kurtz A, Jelkmann W, Bauer C 1982 A new candidate for the regulation of erythropoiesis. Insulin-like growth factor I. FEBS Lett 149:105-108

23. Hizuka N, Takano K, Shizume K, Asakawa K, Miyakawa M, Tanaka I, Horikawa R 1986 Insulin-like growth factor 1 stimulates growth in normal growing rats. Eur J Pharmacol 125:143-146

24. Schoenle E, Zapf J, Hauri C, Steiner T, Froesch ER 1985 Comparison of in vivo effects of insulin-like growth factors I and II and of growth hormone in hypophysectomized rats. Acta Endocrinol 108:167-174

25. Skottner A, Clark RG, Robinson ICAF, Fryklund L 1987 Recombinant human insulin-like growth factor: testing the somatomedin hypothesis in hypophysectomized rats. J Endocrinol 112:123-132

26. van Bull-Offers S, Ueda I, Van den Brande JL 1986 Biosynthetic somatomedin $\mathrm{C}(\mathrm{Sm}-\mathrm{C} / \mathrm{IGF}-\mathrm{I})$ increases the length and weight of Snell dwarf mice. Pediatr Res 20:825-827

27. Reid JD 1960 Congenital absence of the pituitary gland. J Pediatr 56:658-664

28. Brinsmead MW, Liggins GC 1979 Serum somatomedin activity after hypophysectomy and during parturition in fetal lambs. Endocrinology 105:297-305

29. Walker DG, Simpson ME, Asling CW, Evans HM 1950 Growth and differentiation in rat following hypophysectomy at 6 days of age. Anat Rec 106:539-554

30. Moses AC, Nissley SP, Short PA, Rechler MM, White RM, Knight AB, Higa OZ 1980 Increased levels of multiplication-stimulating activity, an insulinlike growth factor, in fetal rat serum. Proc Natl Acad Sci USA 77:3649-3653

31. D'Ercole AJ, Hill DJ, Strain AJ, Underwood LE 1986 Tissue and plasma somatomedin-C/insulin-like growth factor I concentrations in the human fetus during the first half of gestation. Pediatr Res 20:253-255

32. Lowy C, Schiff D 1968 Urinary excretion of insulin in the healthy newborn. Lancet 1:225-227

33. Winick M, Noble A 1965 Quantitative changes in DNA, RNA, and protein during prenatal and postnatal growth in the rat. Dev Biol 12:451-466

34. Sands J, Dobbing J, Gratrix CA 1979 Cell number and cell size: organ growth and development and the control of catch-up growth in rats. Lancet 2:503505

35. Clemmons DR 1984 Multiple hormones stimulate the production of somatomedin by cultured human fibroblasts. J Clin Endocrinol Metab 58:850-856

36. Fischer JW 1983 Control of erythropoietin production. Proc Soc Exp Biol Med 173:289-305

37. Cotes PM 1971 II. In vivo bioassay of erythropoietin. In: Fischer JW (ed) Kidney Hormones, Vol I. Academic Press, New York, pp 244-258

38. Lucarelli G, Porcellini A, Carnevali C, Carmena A, Stholman F Jr 1968 Fetal and neonatal erythropoiesis. Ann NY Acad Sci 149:544-559

39. Smith JM, Sporn MB, Roberts AB, Derynck R, Winkler ME, Gregory H 1985 Human transforming growth factor- $\alpha$ causes precocious eyelid opening in newborn mice. Nature 315:515-516

40. Carpenter $\mathrm{G} 1978$ The regulation of cell proliferation: advances in the biology and mechanism of action of epidermal growth factor. J Invest Dermatol $71: 283-287$ 